\title{
Prediksi Permintaan Mata Kuliah pada Semester Padat Dengan Menggunakan Teknik Association Rule Dengan Algoritma Apriori pada Fakultas Teknologi Informasi Universitas Advent Indonesia
}

\author{
Joan Yuliana Hutapea \\ Fakultas Ekonomi Universitas Advent Indonesia \\ e-mail : joan.hutapea@unai.edu
}

\begin{abstract}
Abstrak
Semester padat adalah suatu periode perkuliahan yang dilaksanakan oleh sebuah lembaga pendidikan/universitas dengan tujuan untuk memfasilitasi mahasiswa yang berkeinginan untuk mempersingkat waktu perkuliahannya, maupun yang berkeinginan untuk memperbaiki nilai mata kuliah sebelumnya yang kurang memadai. Pada semester ini, persiapan yang dilakukan mengacu pada permintaan mahasiswa terhadap mata kuliah tertentu yang ingin diikutinya pada semester padat tersebut. Agar persiapan ini dapat berlangsung dengan baik, pimpinan fakultas perlu memprediksi mata kuliah apa saja yang kemungkinan akan diambil oleh mahasiswa, sehingga mereka dapat mempersiapkan kegiatan pendaftaran dan penugasan dosen terkait dengan mata kuliah tersebut. Tujuan dari penelitian ini adalah untuk melakukan pendataan atas permintaan terhadap mata kuliah dengan menggunakan data historis sebelumnya. Teknik data mining yang digunakan adalah Association Rule dengan menggunakan algoritma apriori untuk mencari frequent itemset sehingga diharapkan prediksi terhadap permintaan mata kuliah ini dapat diketahui. Dari hasil perhitungan dan analisa terhadap 25 data peserta semester padat tahun 2016/2017 di Fakultas Teknologi Informasi, diperoleh tingkat support dan confident yang tinggi terhadap beberapa kombinasi mata kuliah. Selain itu didapati pula bahwa rule dengan nilai asosiasi final tertinggi ada pada rule "If choose $B$ then choose $K$ ", yaitu : Jika mahasiswa memilih mata kuliah B (Algoritma), maka ia juga akan memilih mata kuliah K (Praktek Algoritma) dengan nilai support $20 \%$ dan confidence $100 \%$.
\end{abstract}

Kata kunci: Data Mining, Association Rule, Algoritma Apriori

\section{Prediction of Subject Requests in Short Semester by Using Engineering Association Rules with Apriori Algorithms at Fakultas Teknologi Informasi Universitas Advent Indonesia}

\begin{abstract}
Short semester is a period of lectures carried out by an educational institution / university with the aim of facilitating students who wish to shorten their lecture time, as well as those who wish to improve their grades that are inadequate. In this semester, the preparations made refer to the student's request for certain courses that he wants to attend. In order to make a good preparation, the faculty leaders need to predict what courses are likely to be taken by students, so that they can prepare the registration and assign the lecturers whose related to the course. The purpose of this study is to collect data of students request for certain courses useing previous data. For data mining technique, the author used the Association Rule and apriori algorithm to find the frequent itemset to make prediction. By analyzing 25 participant data of students at the Faculty of Information Technology, on short semester of the academic year 20162017, the resuts shows that there was a high level of support and confidence in several combinations of subjects. In addition, it is also found that the rule with the highest final association value is in the rule of "Choose B then choose K", namely: If the student chooses course B (Algorithm), then he will also choose course $K$ (Algorithm Practice) with the value of support $20 \%$ and $100 \%$ confidence.
\end{abstract}

Keywords: Data Mining, Association Rule, Apriori Algorithm 


\section{Pendahuluan}

Kegiatan akademik yang berlangsung dalam sebuah lembaga pendidikan umumnya terbagi ke dalam 2 (dua) periode, yaitu periode semester ganjil dan semester genap. Namun dengan adanya kebutuhan dan keinginan mahasiswa untuk menyelesaikan pendidikannya dengan lebih cepat, beberapa universitas menyelenggarakan kegiatan perkuliahan pada semester antara, yaitu suatu periode di antara akhir semester genap dan menjelang semester ganjil tahun akademik berikutnya. Semester antara yang juga dikenal dengan istilah semester pendek atau semester padat dilaksanakan pada saat liburan menjelang tahun akademik yang baru. Di Universitas Advent Indonesia, semester padat dilaksanakan pada bulan Juni hingga Juli. Tujuan dari pelaksanaan semester padat ini adalah untuk memfasilitasi mahasiswa yang ingin mempercepat penyelesaian tuntutan SKS kuliah serta memfasilitasi mahasiswa yang ingin memperbaiki mata kuliah dengan nilai kurang memadai agar masa berkuliah normal tidak terganggu. Pada setiap periode semester padat, mahasiswa diizinkan memilih dan mengambil mata kuliah dengan bobot 7 hingga 9 SKS. Dengan adanya semester padat ini, mahasiswa dapat mempersingkat waktu kuliahnya bilamana ia secara rutin mengikuti semester padat tersebut.

Dalam setiap penyelenggaraan semester padat, pimpinan fakultas perlu memprediksi mata kuliah apa saja yang kemungkinan akan diambil oleh mahasiswa, sehingga mereka dapat mempersiapkan kegiatan pendaftaran dan penugasan dosen terkait dengan mata kuliah tersebut. Tujuan dari penelitian ini adalah untuk melakukan pendataan atas permintaan terhadap mata kuliah dengan menggunakan data historis sebelumnya. Teknik data mining yang digunakan adalah Association Rule dengan menggunakan algoritma apriori untuk mencari frequent itemset sehingga diharapkan prediksi terhadap permintaan mata kuliah ini dapat diketahui serta dapat digunakan sebagai acuan pada semester padat berikutnya dan mempermudah dalam proses persiapan pendaftaran serta penugasan dosen pengajar pada semester padat tersebut.

\section{Metode Penelitian}

\section{Data Mining}

Data mining adalah sebuah proses pengumpulan data/informasi untuk menemukan pola-pola tertentu dari sekumpulan data dalam jumlah yang besar, sebagaimana diungkapkan oleh Han dkk [1] "Data mining is the process of discovering interesting patterns and knowledge from large amounts of data. The data sources can include databases, data warehouses, the Web, other information repositories, or data that are streamed into the system dynamically'. Dalam terjemahan bebasnya, data mining adalah proses menemukan pengetahuan dan pola yang menarik dari sejumlah besar data. Sumber data dapat mencakup basis data, gudang data, Web, repositori informasi lain, atau data yang dialirkan ke dalam sistem secara dinamis. Dalam penelitian ini, metode data mining yang digunakan adalah frequent pattern mining untuk menemukan asosiasi dan korelasi yang menarik di antara itemset.

\section{Analisa Asosiasi}

Analisa asosiasi (Association Rule) merupakan teknik data mining untuk mencari pola hubungan dalam data atau basis data. Association Rule digunakan untuk mencari hubungan yang menarik dari sekumpulan data besar, sebagaimana diungkapkan oleh Kaur, dkk. [2] "Association rule mining is useful for discovering interesting relationships hidden in large data sets". Penggunaan association rule yang paling populer adalah Market Basket Analysis (MBA). Teknik MBA ini digunakan untuk mencari pelanggan pada sebuah toko yang biasanya membeli barang $X$, akan membeli barang $Y$ dan seterusnya [3]. Contoh yang sering digunakan dari aturan asosiasi ini antara lain untuk menganalisa buying behavioratau perilaku membeli dari konsumen di suatu pasar swalayan, dengan memprediksi seberapa besar kemungkinan seorang pelanggan membeli item $A$ bersamaan dengan item $B$, atau seberapa besar kemungkinan pelanggan tersebut membeli produk roti bersamaan dengan produk susu. Dengan menganalisa hal tersebut, pemilik pasar swalayan dapat melakukan pengaturan terhadap penempatan barang, atau merencanakan program pemasaran dengan memberikan diskon terhadap kombinasi barang tertentu. 
Prediksi Permintaan Mata Kuliah pada Semester Padat Dengan Menggunakan Teknik Association Rule Dengan Algoritma Apriori pada Fakultas Teknologi Informasi Universitas Advent Indonesia

Teknik Association rule adalah sebuah proses yang terdiri atas 2 (dua) tahap, sebagaimana diungkapkan oleh Han,dkk. [1] "In general, association rule mining can be viewed as a two-step process:

1. Find all frequent itemsets: By definition, each of these itemsets will occur at least as frequently as a predetermined minimum support count, min sup.

2. Generate strong association rules from the frequent itemsets: By definition, these rules must satisfy minimum support and minimum confidence".

Dalam terjemahan bebasnya: secara umum teknik Association rule ini dapat dilihat sebagai proses 2 tahap:

1. Temukan semua itemset yang sering muncul. Tiap itemset muncul setidaknya sejumlah nilai dukungan (support) minimum yang telah ditentukan.

2. Membuat aturan asosiasi/association rule yang kuat dari itemset yang sering muncul, dengan pengertian harus memenuhi dukungan (support) dan kepercayaan (confidence) minimum.

\section{Algoritma Apriori}

Algoritma Apriori adalah suatu algoritma yang banyak digunakan dalam proses pencarian frequent itemset dengan menggunakan teknik association rule. Algoritma Apriori menggunakan knowledge mengenai frequent itemset yang telah diketahui sebelumnya, untuk memproses informasi selanjutnya [4].

Ada dua proses utama yang dilakukan dalam algoritma Apriori [1], yaitu :

1. Join (penggabungan).

Pada proses ini setiap item dikombinasikan dengan item yang lainnya sampai tidak terbentuk kombinasi lagi.

2. Prune (pemangkasan).

Pada proses ini, hasil dari item yang telah dikombinasikan tadi lalu dipangkas dengan menggunakan minimum support yang telah ditentukan oleh user.

Algoritma Apriori digunakan untuk mencari frequent itemsets dari sekumpulan data, analisis ini didefinisikan sebagai "suatu proses untuk menemukan semua aturan apriori yang memenuhi syarat minimum untuk support dan syarat minimum untuk confidence", [5]. Support merupakan nilai persentase kombinasi item dalam database, sedangkan confidence adalah nilai yang menunjukkan kuatnya hubungan antar item dalam sebuah apriori. Rumus support dan confidence adalah sebagai berikut [5] :

$$
\begin{gathered}
\text { Support }(\mathrm{A})=\frac{\text { Jumla transaksi mengandung } A}{\text { Total transaksi }} \times 100 \% \\
\text { Confidence } P(P \mid A)=\frac{\text { Total transaksi mengandung Adan } B}{\text { Transaksi mengandung } A} \times 100 \%
\end{gathered}
$$

\section{Penelitian Terkait (Related Research)}

Penelitian sebelumnya terkait dengan penggunaan teknik association rule dan algoritma apriori telah banyak dilakukan untuk tujuan yang serupa, yakni memprediksi permintaan maupun perilaku memilih dari sejumlah individu terhadap suatu produk ataupun sesuatu hal. Penelitian yang dilakukan sebelumnya [6] [7] [8], menggunakan teknik association rule dan algoritma apriori untuk mengetahui perilaku membeli (buying behavior) produk-produk tertentu dari konsumen di suatu toko atau pasar swalayan. Selanjutnya penelitian yang dilakukan oleh Widodo [3] menggunakan teknik association rule untuk memprediksi permintaan mata kuliah pilihan untuk memutuskan apakah mata kuliah tersebut dibuka atau ditutup dengan menggunakan data historis pada tahun-tahun sebelumnya. Dalam penelitian ini, peneliti menitik beratkan pada permintaan mata kuliah yang ingin diambil mahasiswa pada semester padat, dengan menggunakan data historis semester padat tahun sebelumnya. 


\section{Pengumpulan Data}

Proses pengumpulan data dilakukan dengan cara mengumpulkan data mahasiswa peserta semester padat dari Biro Administrasi Akademik. Secara khusus data yang dikumpulkan adalah data mahasiswa fakultas teknologi informasi yang mengikuti perkuliahan semester padat pada tahun akademik 2016/2017. Setelah data dikumpulkan, selanjutnya dilakukan tahap pembentukan Association Rule.

\section{Pembahasan}

Dengan menggunakan teknik association rule sebagaimana disebutkan di atas, maka akan dilakukan prediksi permintaan mata kuliah dengan data berikut ini.

1. Tabel 1 adalah data peserta dan mata kuliah yang diambil oleh mahasiswa fakultas teknologi informasi pada semester padat tahun akademik (TA) 2016/2017.

Tabel 1 PESERTA SEMESTER PADAT FAKULTAS TI 2016/2017

\begin{tabular}{|c|c|c|c|c|c|}
\hline No & NIM & JURUSAN & $\begin{array}{c}\text { KODE } \\
\text { MATAKULIAH }\end{array}$ & $\begin{array}{c}\text { NAMA } \\
\text { MATAKULIAH }\end{array}$ & \begin{tabular}{|c} 
JUMLAH \\
SKS \\
\end{tabular} \\
\hline \multirow[t]{3}{*}{1} & 1281021 & Teknik Informatika & MSI4730 & Teknologi Baru dan Inovasi SI & 3 \\
\hline & & & TIF3600 & Teori Bahasa dan Otomata & 3 \\
\hline & & & TIK2403 & Jaringan Komputer & 3 \\
\hline 2 & 1281031 & Teknik Informatika & TIK4801 & Skripsi II (Baby Thesis II) & 4 \\
\hline \multirow[t]{2}{*}{3} & 1381024 & Teknik Informatika & TIK2403 & Jaringan Komputer & 3 \\
\hline & & & ENG1206 & Bahasa Inggris II (Reading) & 2 \\
\hline 4 & 1382004 & Sistem Informasi & TIK4801 & Skripsi II (Baby Thesis II) & 4 \\
\hline \multirow[t]{3}{*}{5} & 1481007 & Teknik Informatika & TEO2109 & $\begin{array}{l}\text { Falsafah Pendidikan Kristen \& Roh } \\
\text { Nubuat }\end{array}$ & 3 \\
\hline & & & TIF3600 & Teori Bahasa dan Otomata & 3 \\
\hline & & & TIK2301 & Aljabar Linier & 3 \\
\hline \multirow[t]{3}{*}{6} & 1481019 & Teknik Informatika & MSI4730 & Teknologi Baru dan Inovasi SI & 3 \\
\hline & & & TIK2301 & Aljabar Linier & 3 \\
\hline & & & TIK2403 & Jaringan Komputer & 3 \\
\hline \multirow[t]{2}{*}{7} & 1581006 & Teknik Informatika & MSI4730 & Teknologi Baru dan Inovasi SI & 3 \\
\hline & & & TIF3600 & Teori Bahasa dan Otomata & 3 \\
\hline \multirow[t]{3}{*}{8} & 1581009 & Teknik Informatika & MSI4730 & Teknologi Baru dan Inovasi SI & 3 \\
\hline & & & TIF3600 & Teori Bahasa dan Otomata & 3 \\
\hline & & & TIK2301 & Aljabar Linier & 3 \\
\hline \multirow[t]{3}{*}{9} & 1581017 & Teknik Informatika & MSI4730 & Teknologi Baru dan Inovasi SI & 3 \\
\hline & & & TIF3600 & Teori Bahasa dan Otomata & 3 \\
\hline & & & TIK2403 & Jaringan Komputer & 3 \\
\hline \multirow[t]{3}{*}{10} & 1581025 & Teknik Informatika & MSI4730 & Teknologi Baru dan Inovasi SI & 3 \\
\hline & & & TIF3600 & Teori Bahasa dan Otomata & 3 \\
\hline & & & TIK2403 & Jaringan Komputer & 3 \\
\hline
\end{tabular}


Prediksi Permintaan Mata Kuliah pada Semester Padat Dengan Menggunakan Teknik Association Rule Dengan Algoritma Apriori pada Fakultas Teknologi Informasi Universitas Advent Indonesia

\begin{tabular}{|c|c|c|c|c|c|}
\hline No & NIM & JURUSAN & $\begin{array}{c}\text { KODE } \\
\text { MATAKULIAH } \\
\end{array}$ & $\begin{array}{c}\text { NAMA } \\
\text { MATAKULIAH }\end{array}$ & $\begin{array}{c}\text { JUMLAH } \\
\text { SKS }\end{array}$ \\
\hline \multirow[t]{3}{*}{11} & 1581029 & Teknik Informatika & MSI4730 & Teknologi Baru dan Inovasi SI & 3 \\
\hline & & & TIF3600 & Teori Bahasa dan Otomata & 3 \\
\hline & & & TIK2403 & Jaringan Komputer & 3 \\
\hline \multirow[t]{3}{*}{12} & 1582007 & Sistem Informasi & KOM363 & Teori Bahasa dan Otomata & 3 \\
\hline & & & TIK2403 & Jaringan Komputer & 3 \\
\hline & & & TEO2206 & Daniel dan Wahyu & 3 \\
\hline \multirow[t]{3}{*}{13} & 1582009 & Sistem Informasi & KOM363 & Teori Bahasa dan Otomata & 3 \\
\hline & & & MSI4730 & Teknologi Baru dan Inovasi SI & 3 \\
\hline & & & TIK2403 & Jaringan Komputer & 3 \\
\hline \multirow[t]{2}{*}{14} & 1582014 & Sistem Informasi & KOM363 & Teori Bahasa dan Otomata & 3 \\
\hline & & & TIK2403 & Jaringan Komputer & 3 \\
\hline \multirow[t]{3}{*}{15} & 1582016 & Sistem Informasi & KOM363 & Teori Bahasa dan Otomata & 3 \\
\hline & & & MSI4730 & Teknologi Baru dan Inovasi SI & 3 \\
\hline & & & TIK2403 & Jaringan Komputer & 3 \\
\hline \multirow[t]{4}{*}{16} & 1582017 & Sistem Informasi & MSI4730 & Teknologi Baru dan Inovasi SI & 3 \\
\hline & & & TIF1206 & Praktikum Algoritma \& Pemrograman II & 1 \\
\hline & & & TIF1209 & Algoritma dan Pemrograman II & 2 \\
\hline & & & TIK2403 & Jaringan Komputer & 3 \\
\hline 17 & 1582019 & Sistem Informasi & TIK2403 & Jaringan Komputer & 3 \\
\hline \multirow[t]{4}{*}{18} & 1582020 & Sistem Informasi & KOM363 & Teori Bahasa dan Otomata & 3 \\
\hline & & & MSI4730 & Teknologi Baru dan Inovasi SI & 3 \\
\hline & & & TIF1206 & Praktikum Algoritma \& Pemrograman II & 1 \\
\hline & & & TIF1209 & Algoritma dan Pemrograman II & 2 \\
\hline \multirow[t]{4}{*}{19} & 1582021 & Sistem Informasi & MSI4730 & Teknologi Baru dan Inovasi SI & 3 \\
\hline & & & TIF1206 & Praktikum Algoritma \& Pemrograman II & 1 \\
\hline & & & TIF1209 & Algoritma dan Pemrograman II & 2 \\
\hline & & & TIK2403 & Jaringan Komputer & 3 \\
\hline \multirow[t]{4}{*}{20} & 1582027 & Sistem Informasi & KOM363 & Teori Bahasa dan Otomata & 3 \\
\hline & & & TIF1206 & Praktikum Algoritma \& Pemrograman II & 1 \\
\hline & & & TIF1209 & Algoritma dan Pemrograman II & 2 \\
\hline & & & TIK2403 & Jaringan Komputer & 3 \\
\hline \multirow[t]{4}{*}{21} & 1582030 & Sistem Informasi & MSI4730 & Teknologi Baru dan Inovasi SI & 3 \\
\hline & & & TIF1206 & Praktikum Algoritma \& Pemrograman II & 1 \\
\hline & & & TIF1209 & Algoritma dan Pemrograman II & 2 \\
\hline & & & TIK2403 & Jaringan Komputer & 3 \\
\hline \multirow[t]{3}{*}{22} & 1681009 & Teknik Informatika & MSI4730 & Teknologi Baru dan Inovasi SI & 3 \\
\hline & & & TEO2109 & $\begin{array}{l}\begin{array}{l}\text { Falsafah Pendidikan Kristen \& Roh } \\
\text { Nubuat }\end{array} \\
\text { \& }\end{array}$ & 3 \\
\hline & & & TIK2301 & Aljabar Linier & 3 \\
\hline \multirow[t]{2}{*}{23} & 1681025 & Teknik Informatika & TIF1206 & Praktikum Algoritma \& Pemrograman II & 1 \\
\hline & & & TEO2210 & Doktrin Alkitab & 2 \\
\hline \multirow[t]{3}{*}{24} & 1682001 & Sistem Informasi & MSI4730 & Teknologi Baru dan Inovasi SI & 3 \\
\hline & & & TIK2301 & Aljabar Linear & 3 \\
\hline & & & TIK2403 & Jaringan Komputer & 3 \\
\hline \multirow[t]{2}{*}{25} & 1682030 & Sistem Informasi & TEO2109 & $\begin{array}{l}\text { Falsafah Pendidikan Kristen \& Roh } \\
\text { Nubuat }\end{array}$ & 3 \\
\hline & & & TEO2206 & Daniel dan Wahyu & 3 \\
\hline
\end{tabular}


2. Selanjutnya data pada Tabel 1 tersebut diklasifikasi berdasarkan jumlah peserta pada tiap-tiap mata kuliah. Tabel 2 merupakan hasil pengklasifikasian transaksi untuk 1 itemset (F1)

\begin{tabular}{|c|c|c|c|c|c|c|c|c|c|c|c|c|c|}
\hline \multicolumn{14}{|c|}{ Tabel 2. Klasifikasi transaksi untuk 1 (satu) item set (F1) } \\
\hline & & & & & & & & & & & & & \\
\hline \multirow{3}{*}{ Input } & Tahun & & Skripsi & Algoritma & Doktrin & B.Ingg & Daniel & Tekno & Teori & Jarkom & Falsafah & Aljabar & Prak \\
\hline & Akad & Mata Kuliah yang di ambil & 2 & 2 & Alkitab & 2 & Wahyu & Baru & Otomata & & & Linier & Alpro \\
\hline & & & $\mathbf{A}$ & B & C & D & E & F & $\mathbf{G}$ & $\mathrm{H}$ & $\mathrm{I}$ & $\mathrm{J}$ & K \\
\hline 1 & $2016 / 2017$ & $\{$ Teknologi Baru, Teori Otomata, Jarkom\} & & & & & & 1 & 1 & 1 & & & \\
\hline 2 & $2016 / 2017$ & $\{$ Skripsi 2\} & 1 & & & & & & & & & & \\
\hline 3 & $2016 / 2017$ & $\{$ JJarkom, B.ingg 2\} & & & & 1 & & & & 1 & & & \\
\hline 4 & $2016 / 2017$ & $\{$ Skripsi 2\} & 1 & & & & & & & & & & \\
\hline 5 & $2016 / 2017$ & \{Falsafah, Teori Otomata, Aljabar Linier\} & & & & & & & 1 & & 1 & 1 & \\
\hline 6 & $2016 / 2017$ & \{Teknologi Baru, Aljabar Linier, Jarkom\} & & & & & & 1 & & 1 & & 1 & \\
\hline 7 & $2016 / 2017$ & $\{$ Teknologi Baru, Teori Otomata $\}$ & & & & & & 1 & 1 & & & & \\
\hline 8 & $2016 / 2017$ & $\{$ TTeknologi Baru, Teori Otomata, Aljabar Linier\} & & & & & & 1 & 1 & & & 1 & \\
\hline 9 & $2016 / 2017$ & \{Teknologi Baru, Teori Otomata, Jarkom\} & & & & & & 1 & 1 & 1 & & & \\
\hline 10 & $2016 / 2017$ & $\{$ TTeknologi Baru, Teori Otomata, Jarkom\} & & & & & & 1 & 1 & 1 & & & \\
\hline 11 & $2016 / 2017$ & $\{$ Teknologi Baru, Teori Otomata, Jarkom\} & & & & & & 1 & 1 & 1 & & & \\
\hline 12 & $2016 / 2017$ & $\{$ TTeori Otomata, Jarkom, Daniel Wahy u\} & & & & & 1 & & 1 & 1 & & & \\
\hline 13 & $2016 / 2017$ & $\{$ TTeori Otomata, Teknologi Baru, Jarkom\} & & & & & & 1 & 1 & 1 & & & \\
\hline 14 & $2016 / 2017$ & $\{$ TTeori Otomata, Jarkom\} & & & & & & & 1 & 1 & & & \\
\hline 15 & $2016 / 2017$ & $\{$ TTeori Otomata, Teknologi Baru, Jarkom\} & & & & & & 1 & & 1 & & & \\
\hline 16 & $2016 / 2017$ & $\{$ Teknologi Baru, PrakAlpro, Agoritma 2, Jarkom\} & & 1 & & & & 1 & & 1 & & & 1 \\
\hline 17 & $2016 / 2017$ & $\{$ Jarkom $\}$ & & & & & & & & 1 & & & \\
\hline 18 & $2016 / 2017$ & $\{$ TTeori otomata, Teknologi Baru, PrakAlpro, Agoritma 2\} & & 1 & & & & 1 & 1 & & & & 1 \\
\hline 19 & $2016 / 2017$ & $\{$ Teknologi Baru, PrakAlpro, Agoritma 2, Jarkom\} & & 1 & & & & 1 & & 1 & & & 1 \\
\hline 20 & $2016 / 2017$ & $\{$ Teori Otomata, PrakAlpro, Agoritma 2, Jarkom\} & & 1 & & & & & 1 & 1 & & & 1 \\
\hline 21 & $2016 / 2017$ & \{Teknologi Baru, PrakAlpro, Agoritma 2, Jarkom\} & & 1 & & & & 1 & & 1 & & & 1 \\
\hline 22 & $2016 / 2017$ & $\{$ TTeknologi Baru, Falsafah, Aljabar Linier\} & & & & & & 1 & & & 1 & 1 & \\
\hline 23 & $2016 / 2017$ & $\{$ PrakAlpro, Doktrin Alkitab\} & & & 1 & & & & & & & & 1 \\
\hline 24 & $2016 / 2017$ & $\{$ TTeknologi Baru, Aljabar Linier, Jarkom\} & & & & & & 1 & & 1 & & 1 & \\
\hline
\end{tabular}

Untuk mempermudah penganalisaan, setiap mata kuliah diberikan kode singkat berikut ini:

\begin{tabular}{|c|c|c|c|c|c|c|c|c|c|c|c|c|}
\hline & Skripsi & Algoritma & Doktrin & B.Ingg & Daniel & Tekno & Teori & Jarkom & Falsafah & Aljabar & Prak \\
MATA KULIAH & $\mathbf{2}$ & $\mathbf{2}$ & Alkitab & $\mathbf{2}$ & Wahyu & Baru & Otomata & & & Linier & Alpro \\
\hline KODE SINGKAT & A & B & C & D & E & F & G & H & I & J & K \\
\hline
\end{tabular}

3. Menentukan $\operatorname{phi}(\phi) \geq 3$

phi $(\phi)$ diperoleh dengan ketentuan yaitu: satu mata kuliah diikuti oleh minimum 3 peserta. Hasil pada tabel 2 di atas menunjukkan, untuk $k=1$ terdapat 7 mata kuliah yang nilainya memenuhi ketentuan phi $(\phi) \geq 3$.

maka, $\mathrm{F} 1=(\mathrm{B}, \mathrm{F}, \mathrm{G}, \mathrm{H}, \mathrm{I}, \mathrm{J}, \mathrm{K})$ untuk $\mathrm{k}=2$ (2 unsur) diperlukan tabel untuk tiap-tiap pasang item. Himpunan yang dapat terbentuk adalah:

Tabel 3 Himpunan yang terbentuk untuk 2 item set

\begin{tabular}{|l|l|l|l|l|l|l|l|l|l|l|l|}
\hline B F & F G & G & H & H I & I J & J K \\
\hline B & G & F & H & G & H & H J & I & K & & \\
\hline B & H & F & F & G & J & H & K & & & & \\
\hline B & J & F & K & & & & & & & & \\
\hline B & K & & & & & & & & & & \\
\hline
\end{tabular}


4. Selanjutnya disusun tabel untuk 2 itemset, dengan hasil sebagai berikut :

Tabel 4 Klasifikasi Transaksi untuk 2 (dua) itemset, (F2)

\begin{tabular}{|r|r|r|l|}
\hline Input & $B$ & $F$ & $f$ \\
\hline 1 & & 1 & $S$ \\
\hline 2 & & & $S$ \\
\hline 3 & & & $S$ \\
\hline 4 & & & $S$ \\
\hline 5 & & & $S$ \\
\hline 6 & & 1 & $S$ \\
\hline 7 & & 1 & $S$ \\
\hline 8 & & 1 & $S$ \\
\hline 9 & & 1 & $S$ \\
\hline 10 & & 1 & $S$ \\
\hline 11 & & 1 & $S$ \\
\hline 12 & & & $S$ \\
\hline 13 & & 1 & $S$ \\
\hline 14 & & & $S$ \\
\hline 15 & & 1 & $S$ \\
\hline 16 & 1 & 1 & $P$ \\
\hline 17 & & & $S$ \\
\hline 18 & 1 & 1 & $P$ \\
\hline 19 & 1 & 1 & $P$ \\
\hline 20 & 1 & & $S$ \\
\hline 21 & 1 & 1 & $P$ \\
\hline 22 & & 1 & $S$ \\
\hline 23 & & & $S$ \\
\hline 24 & & 1 & $S$ \\
\hline 25 & & & $S$ \\
\hline & & $\Sigma$ & 4 \\
\hline & & \\
\hline
\end{tabular}

\begin{tabular}{|r|r|r|l|}
\hline nput & B & $G$ & $f$ \\
\hline 1 & & 1 & $S$ \\
\hline 2 & & & $S$ \\
\hline 3 & & & $S$ \\
\hline 4 & & & $S$ \\
\hline 5 & & 1 & $S$ \\
\hline 6 & & & $S$ \\
\hline 7 & & 1 & $S$ \\
\hline 8 & & 1 & $S$ \\
\hline 9 & & 1 & $S$ \\
\hline 10 & & 1 & $S$ \\
\hline 11 & & 1 & $S$ \\
\hline 12 & & 1 & $S$ \\
\hline 13 & & 1 & $S$ \\
\hline 14 & & 1 & $S$ \\
\hline 15 & & & $S$ \\
\hline 16 & 1 & & $S$ \\
\hline 17 & & & $S$ \\
\hline 18 & 1 & 1 & $P$ \\
\hline 19 & 1 & & $S$ \\
\hline 20 & 1 & 1 & $P$ \\
\hline 21 & 1 & & $S$ \\
\hline 22 & & & $S$ \\
\hline 23 & & & $S$ \\
\hline 24 & & & $S$ \\
\hline 25 & & & $S$ \\
\hline & & $\Sigma$ & 2 \\
\hline
\end{tabular}
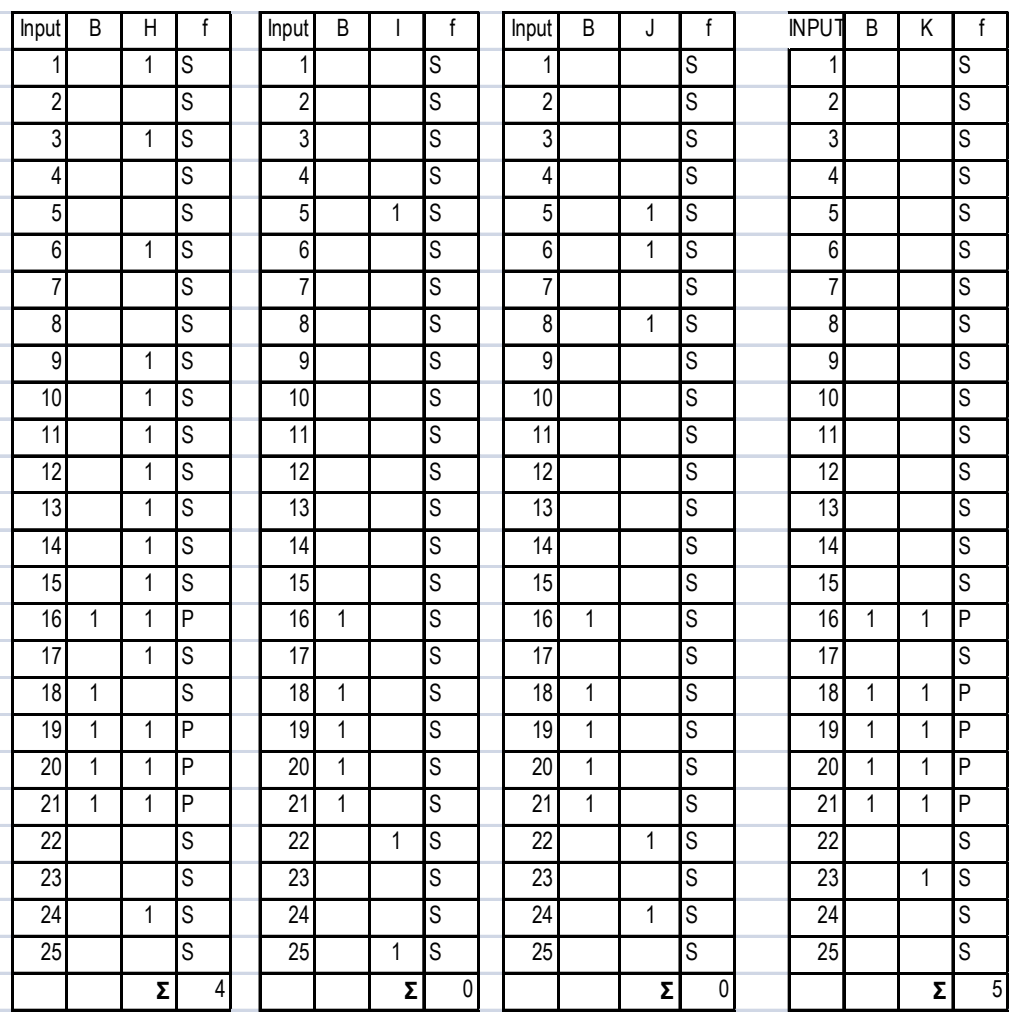

\begin{tabular}{|c|c|c|c|}
\hline input & $\mathrm{F}$ & $\mathrm{G}$ & $f$ \\
\hline 1 & 1 & 1 & $S$ \\
\hline 2 & & & $S$ \\
\hline 3 & & & $S$ \\
\hline 4 & & & $S$ \\
\hline 5 & & 1 & $\mathrm{~S}$ \\
\hline 6 & 1 & & $\mathrm{~S}$ \\
\hline 7 & 1 & 1 & $P$ \\
\hline 8 & 1 & 1 & $\mathrm{P}$ \\
\hline 9 & 1 & 1 & $\mathrm{P}$ \\
\hline 10 & 1 & 1 & $P$ \\
\hline 11 & 1 & 1 & $P$ \\
\hline 12 & & 1 & $\mathrm{~S}$ \\
\hline 13 & 1 & 1 & $\mathrm{P}$ \\
\hline 14 & & 1 & $S$ \\
\hline 15 & 1 & & $S$ \\
\hline 16 & 1 & & $S$ \\
\hline 17 & & & $S$ \\
\hline 18 & 1 & 1 & $\mathrm{P}$ \\
\hline 19 & 1 & & $\mathrm{~S}$ \\
\hline 20 & & 1 & $\mathrm{~S}$ \\
\hline 21 & 1 & & $S$ \\
\hline 22 & 1 & & $\mathrm{~S}$ \\
\hline 23 & & & $\mathrm{~S}$ \\
\hline 24 & 1 & & $\mathrm{~S}$ \\
\hline 25 & & & $S$ \\
\hline & & $\Sigma$ & \\
\hline
\end{tabular}

\begin{tabular}{|c|c|c|c|}
\hline input & $\mathrm{F}$ & $\mathrm{H}$ & $f$ \\
\hline 1 & 1 & 1 & $P$ \\
\hline 2 & & & $S$ \\
\hline 3 & & 1 & $S$ \\
\hline 4 & & & $S$ \\
\hline 5 & & & $\mathrm{~S}$ \\
\hline 6 & 1 & 1 & $\bar{P}$ \\
\hline 7 & 1 & & S \\
\hline 8 & 1 & & $\mathrm{~S}$ \\
\hline 9 & 1 & 1 & $\mathrm{P}$ \\
\hline 10 & 1 & 1 & $\mathrm{P}$ \\
\hline 11 & 1 & 1 & $P$ \\
\hline 12 & & 1 & $S$ \\
\hline 13 & 1 & 1 & $\mathrm{P}$ \\
\hline 14 & & 1 & $S$ \\
\hline 15 & 1 & 1 & $\mathrm{P}$ \\
\hline 16 & 1 & 1 & $\mathrm{P}$ \\
\hline 17 & & 1 & S \\
\hline 18 & 1 & & S \\
\hline 19 & 1 & 1 & $\mathrm{P}$ \\
\hline 20 & & 1 & $S$ \\
\hline 21 & 1 & 1 & $\mathrm{P}$ \\
\hline 22 & 1 & & S \\
\hline 23 & & & S \\
\hline 24 & 1 & 1 & $\mathrm{P}$ \\
\hline 25 & & & $\mathrm{~S}$ \\
\hline & & $\Sigma$ & \\
\hline
\end{tabular}
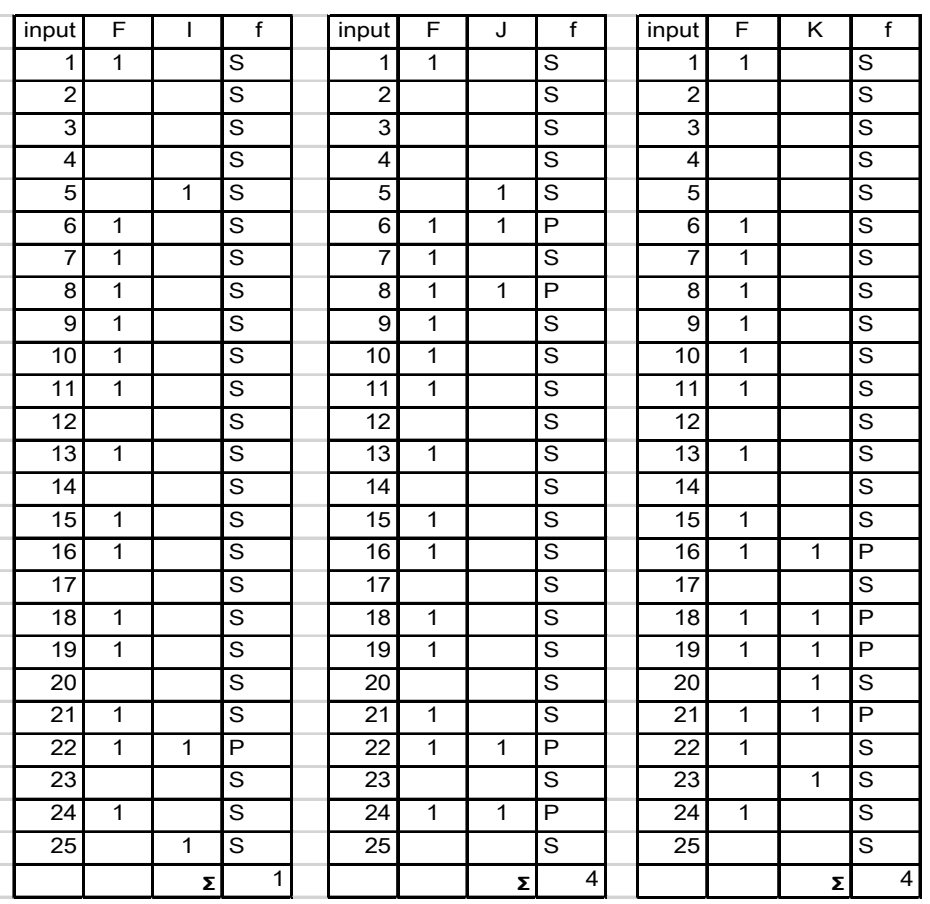


\begin{tabular}{|c|c|c|c|}
\hline input & $\mathrm{G}$ & $\mathrm{H}$ & $f$ \\
\hline 1 & 1 & 1 & $P$ \\
\hline 2 & & & $S$ \\
\hline 3 & & 1 & $S$ \\
\hline 4 & & & $S$ \\
\hline 5 & 1 & & $S$ \\
\hline 6 & & 1 & $S$ \\
\hline 7 & 1 & & $S$ \\
\hline 8 & 1 & & $S$ \\
\hline 9 & 1 & 1 & $P$ \\
\hline 10 & 1 & 1 & $P$ \\
\hline 11 & 1 & 1 & $P$ \\
\hline 12 & 1 & 1 & $P$ \\
\hline 13 & 1 & 1 & $P$ \\
\hline 14 & 1 & 1 & $P$ \\
\hline 15 & & 1 & $S$ \\
\hline 16 & & 1 & $S$ \\
\hline 17 & & 1 & $S$ \\
\hline 18 & 1 & & $S$ \\
\hline 19 & & 1 & $S$ \\
\hline 20 & 1 & 1 & $P$ \\
\hline 21 & & 1 & $S$ \\
\hline 22 & & & $S$ \\
\hline 23 & & & $S$ \\
\hline 24 & & 1 & $S$ \\
\hline \multirow[t]{2}{*}{25} & & & $S$ \\
\hline & & $\bar{\Sigma}$ & 8 \\
\hline
\end{tabular}

\begin{tabular}{|c|c|c|c|}
\hline input & G & 1 & $f$ \\
\hline 1 & 1 & & $S$ \\
\hline 2 & & & $S$ \\
\hline 3 & & & $S$ \\
\hline 4 & & & $S$ \\
\hline 5 & 1 & 1 & $P$ \\
\hline 6 & & & $S$ \\
\hline 7 & 1 & & $S$ \\
\hline 8 & 1 & & $S$ \\
\hline 9 & 1 & & $S$ \\
\hline 10 & 1 & & S \\
\hline 11 & 1 & & $S$ \\
\hline \begin{tabular}{l|}
12 \\
\end{tabular} & 1 & & $S$ \\
\hline 13 & 1 & & $S$ \\
\hline 14 & 1 & & $S$ \\
\hline 15 & & & $S$ \\
\hline 16 & & & $S$ \\
\hline 17 & & & $S$ \\
\hline 18 & 1 & & $S$ \\
\hline 19 & & & $S$ \\
\hline 20 & 1 & & S \\
\hline 21 & & & S \\
\hline 22 & & 1 & $S$ \\
\hline 23 & & & $S$ \\
\hline 24 & & & $S$ \\
\hline 25 & & 1 & $S$ \\
\hline & & $\bar{\Sigma}$ & 1 \\
\hline
\end{tabular}

\begin{tabular}{|c|c|c|c|}
\hline input & $G$ & $\mathrm{~J}$ & $f$ \\
\hline 1 & 1 & & $\bar{S}$ \\
\hline 2 & & & $S$ \\
\hline 3 & & & $S$ \\
\hline 4 & & & $S$ \\
\hline 5 & 1 & 1 & $P$ \\
\hline 6 & & 1 & $S$ \\
\hline 7 & 1 & & $S$ \\
\hline 8 & 1 & 1 & $P$ \\
\hline 9 & 1 & & $S$ \\
\hline 10 & 1 & & $S$ \\
\hline 11 & 1 & & $S$ \\
\hline 12 & 1 & & $S$ \\
\hline 13 & 1 & & $S$ \\
\hline 14 & 1 & & $S$ \\
\hline 15 & & & $S$ \\
\hline 16 & & & $S$ \\
\hline 17 & & & $S$ \\
\hline 18 & 1 & & $S$ \\
\hline 19 & & & $S$ \\
\hline 20 & 1 & & $S$ \\
\hline 21 & & & $S$ \\
\hline 22 & & 1 & $S$ \\
\hline 23 & & & $S$ \\
\hline 24 & & 1 & $S$ \\
\hline 25 & & & $S$ \\
\hline & & $\boldsymbol{\Sigma}$ & 2 \\
\hline
\end{tabular}

\begin{tabular}{|c|c|c|c|}
\hline input & $\bar{G}$ & $\bar{K}$ & $f$ \\
\hline 1 & 1 & & $\bar{S}$ \\
\hline 2 & & & $S$ \\
\hline 3 & & & $\mathrm{~S}$ \\
\hline 4 & & & $\mathrm{~S}$ \\
\hline 5 & 1 & & $S$ \\
\hline 6 & & & $S$ \\
\hline 7 & 1 & & $\mathrm{~S}$ \\
\hline 8 & 1 & & $S$ \\
\hline 9 & 1 & & $\mathrm{~S}$ \\
\hline 10 & 1 & & $\mathrm{~S}$ \\
\hline 11 & 1 & & $\mathrm{~S}$ \\
\hline 12 & 1 & & $\mathrm{~S}$ \\
\hline 13 & 1 & & $S$ \\
\hline 14 & 1 & & $\mathrm{~S}$ \\
\hline 15 & & & $\mathrm{~S}$ \\
\hline 16 & & 1 & $S$ \\
\hline 17 & & & $\mathrm{~S}$ \\
\hline 18 & 1 & 1 & $P$ \\
\hline 19 & & 1 & $S$ \\
\hline 20 & 1 & 1 & $\bar{P}$ \\
\hline 21 & & 1 & $S$ \\
\hline 22 & & & $\bar{S}$ \\
\hline 23 & & 1 & $S$ \\
\hline 24 & & & $\bar{S}$ \\
\hline 25 & & & $S$ \\
\hline & & $\bar{\Sigma}$ & 2 \\
\hline
\end{tabular}

\begin{tabular}{|r|c|c|c|}
\hline input & $\mathrm{H}$ & $\mathrm{I}$ & $\mathrm{f}$ \\
\hline 1 & 1 & & $\mathrm{~S}$ \\
\hline 2 & & & $\mathrm{~S}$ \\
\hline 3 & 1 & & $\mathrm{~S}$ \\
\hline 4 & & & $\mathrm{~S}$ \\
\hline 5 & & 1 & $\mathrm{~S}$ \\
\hline 6 & 1 & & $\mathrm{~S}$ \\
\hline 7 & & & $\mathrm{~S}$ \\
\hline 8 & & & $\mathrm{~S}$ \\
\hline 9 & 1 & & $\mathrm{~S}$ \\
\hline 10 & 1 & & $\mathrm{~S}$ \\
\hline 11 & 1 & & $\mathrm{~S}$ \\
\hline 12 & 1 & & $\mathrm{~S}$ \\
\hline 13 & 1 & & $\mathrm{~S}$ \\
\hline 14 & 1 & & $\mathrm{~S}$ \\
\hline 15 & 1 & & $\mathrm{~S}$ \\
\hline
\end{tabular}

\begin{tabular}{|r|r|r|r|}
\hline input & $\mathrm{H}$ & $\mathrm{I}$ & $\mathrm{f}$ \\
\hline 1 & 1 & & $\mathrm{~S}$ \\
\hline 2 & & & $\mathrm{~S}$ \\
\hline 3 & 1 & & $\mathrm{~S}$ \\
\hline 4 & & & $\mathrm{~S}$ \\
\hline 5 & & 1 & $\mathrm{~S}$ \\
\hline 6 & 1 & 1 & $\mathrm{P}$ \\
\hline 7 & & & $\mathrm{~S}$ \\
\hline 8 & & 1 & $\mathrm{~S}$ \\
\hline 9 & 1 & & $\mathrm{~S}$ \\
\hline 10 & 1 & & $\mathrm{~S}$ \\
\hline 11 & 1 & & $\mathrm{~S}$ \\
\hline 12 & 1 & & $\mathrm{~S}$ \\
\hline 13 & 1 & & $\mathrm{~S}$ \\
\hline 14 & 1 & & $\mathrm{~S}$ \\
\hline 15 & 1 & & $\mathrm{~S}$ \\
\hline
\end{tabular}

\begin{tabular}{|r|r|r|r|}
\hline input & $\mathrm{H}$ & $\mathrm{I}$ & $\mathrm{f}$ \\
\hline 1 & 1 & & $\mathrm{~S}$ \\
\hline 2 & & & $\mathrm{~S}$ \\
\hline 3 & 1 & & $\mathrm{~S}$ \\
\hline 4 & & & $\mathrm{~S}$ \\
\hline 5 & & & $\mathrm{~S}$ \\
\hline 6 & 1 & & $\mathrm{~S}$ \\
\hline 7 & & & $\mathrm{~S}$ \\
\hline 8 & & & $\mathrm{~S}$ \\
\hline 9 & 1 & & $\mathrm{~S}$ \\
\hline 10 & 1 & & $\mathrm{~S}$ \\
\hline 11 & 1 & & $\mathrm{~S}$ \\
\hline 12 & 1 & & $\mathrm{~S}$ \\
\hline 13 & 1 & & $\mathrm{~S}$ \\
\hline 14 & 1 & & $\mathrm{~S}$ \\
\hline 15 & 1 & & $\mathrm{~S}$ \\
\hline
\end{tabular}

\begin{tabular}{|l|l|l|l|l|l|l|l|l|l|l|l|l|l|l|l|l|l|l|l|}
\hline inpput & $\mathrm{H}$ & $\mathrm{I}$ & $\mathrm{f}$ & $\mathrm{I}$ & $\mathrm{f}$ & $\mathrm{I}$ & $\mathrm{f}$ \\
\hline
\end{tabular} 


\begin{tabular}{|l|l|l|l|}
16 & 1 & & $\mathrm{~S}$ \\
\hline 17 & 1 & & $\mathrm{~S}$ \\
\hline 18 & & & $\mathrm{~S}$ \\
\hline 19 & 1 & & $\mathrm{~S}$ \\
\hline 20 & 1 & & $\mathrm{~S}$ \\
\hline 21 & 1 & & $\mathrm{~S}$ \\
\hline 22 & & 1 & $\mathrm{~S}$ \\
\hline 23 & & & $\mathrm{~S}$ \\
\hline 24 & 1 & & $\mathrm{~S}$ \\
\hline 25 & & 1 & $\mathrm{~S}$ \\
\hline & & $\boldsymbol{\Sigma}$ & 0 \\
\hline
\end{tabular}

\begin{tabular}{|l|l|l|l|}
16 & 1 & & $\mathrm{~S}$ \\
\hline 17 & 1 & & $\mathrm{~S}$ \\
\hline 18 & & & $\mathrm{~S}$ \\
\hline 19 & 1 & & $\mathrm{~S}$ \\
\hline 20 & 1 & & $\mathrm{~S}$ \\
\hline 21 & 1 & & $\mathrm{~S}$ \\
\hline 22 & & 1 & $\mathrm{~S}$ \\
\hline 23 & & & $\mathrm{~S}$ \\
\hline 24 & 1 & 1 & $\mathrm{P}$ \\
\hline 25 & & & $\mathrm{~S}$ \\
\hline & & $\mathbf{\Sigma}$ & 2 \\
\hline
\end{tabular}

\begin{tabular}{|l|l|l|l|}
16 & 1 & 1 & $\mathrm{P}$ \\
\hline 17 & 1 & & $\mathrm{~S}$ \\
\hline 18 & & 1 & $\mathrm{~S}$ \\
\hline 19 & 1 & 1 & $\mathrm{P}$ \\
\hline 20 & 1 & 1 & $\mathrm{P}$ \\
\hline 21 & 1 & 1 & $\mathrm{P}$ \\
\hline 22 & & & $\mathrm{~S}$ \\
\hline 23 & & 1 & $\mathrm{~S}$ \\
\hline 24 & 1 & & $\mathrm{~S}$ \\
\hline 25 & & & $\mathrm{~S}$ \\
\hline & & $\boldsymbol{\Sigma}$ & 4 \\
\hline
\end{tabular}

\begin{tabular}{|r|r|r|l|}
\hline input & I & J & F \\
\hline 1 & & & $S$ \\
\hline 2 & & & $S$ \\
\hline 3 & & & $S$ \\
\hline 4 & & & $S$ \\
\hline 5 & 1 & 1 & $P$ \\
\hline 6 & & 1 & $S$ \\
\hline 7 & & & $S$ \\
\hline 8 & & 1 & $S$ \\
\hline 9 & & & $S$ \\
\hline 10 & & & $S$ \\
\hline 11 & & & $S$ \\
\hline 12 & & & $S$ \\
\hline 13 & & & $S$ \\
\hline 14 & & & $S$ \\
\hline 15 & & & $S$ \\
\hline 16 & & & $S$ \\
\hline 17 & & & $S$ \\
\hline 18 & & & $S$ \\
\hline 19 & & & $S$ \\
\hline 20 & & & $S$ \\
\hline 21 & & & $S$ \\
\hline 22 & 1 & 1 & $P$ \\
\hline 23 & & & $S$ \\
\hline 24 & & 1 & $S$ \\
\hline 25 & 1 & & $S$ \\
\hline & & $\boldsymbol{\Sigma}$ & \\
\hline & & \\
\hline & & \\
\hline
\end{tabular}

\begin{tabular}{|r|r|r|l|}
\hline input & I & K & F \\
\hline 1 & & & $S$ \\
\hline 2 & & & $S$ \\
\hline 3 & & & $S$ \\
\hline 4 & & & $S$ \\
\hline 5 & 1 & & $S$ \\
\hline 6 & & & $S$ \\
\hline 7 & & & $S$ \\
\hline 8 & & & $S$ \\
\hline 9 & & & $S$ \\
\hline 10 & & & $S$ \\
\hline 11 & & & $S$ \\
\hline 12 & & & $S$ \\
\hline 13 & & & $S$ \\
\hline 14 & & & $S$ \\
\hline 15 & & & $S$ \\
\hline 16 & & 1 & $S$ \\
\hline 17 & & & $S$ \\
\hline 18 & & 1 & $S$ \\
\hline 19 & & 1 & $S$ \\
\hline 20 & & 1 & $S$ \\
\hline 21 & & 1 & $S$ \\
\hline 22 & 1 & & $S$ \\
\hline 23 & & 1 & $S$ \\
\hline 24 & & & $S$ \\
\hline 25 & 1 & & $S$ \\
\hline & & $\boldsymbol{\Sigma}$ & \\
\hline & & \\
\hline & & $S$ \\
\hline
\end{tabular}

\begin{tabular}{|r|r|r|l|}
\hline input & $\mathrm{J}$ & $\mathrm{K}$ & $\mathrm{F}$ \\
\hline 1 & & & $\mathrm{~S}$ \\
\hline 2 & & & $\mathrm{~S}$ \\
\hline 3 & & & $\mathrm{~S}$ \\
\hline 4 & & & $\mathrm{~S}$ \\
\hline 5 & 1 & & $\mathrm{~S}$ \\
\hline 6 & 1 & & $\mathrm{~S}$ \\
\hline 7 & & & $\mathrm{~S}$ \\
\hline 8 & 1 & & $\mathrm{~S}$ \\
\hline 9 & & & $S$ \\
\hline 10 & & & $S$ \\
\hline 11 & & & $S$ \\
\hline 12 & & & $S$ \\
\hline 13 & & & $S$ \\
\hline 14 & & & $S$ \\
\hline 15 & & & $S$ \\
\hline 16 & & 1 & $S$ \\
\hline 17 & & & $S$ \\
\hline 18 & & 1 & $S$ \\
\hline 19 & & 1 & $S$ \\
\hline 20 & & 1 & $S$ \\
\hline 21 & & 1 & $S$ \\
\hline 22 & 1 & & $S$ \\
\hline 23 & & 1 & $S$ \\
\hline 24 & 1 & & $S$ \\
\hline 25 & & & $S$ \\
\hline & & $\boldsymbol{\Sigma}$ & \\
\hline & & \\
\hline
\end{tabular}

Dari Tabel 2 unsur di atas, P artinya mata kuliah yang diambil/dipilih bersamaan, sedangkan $\mathrm{S}$ artinya tidak ada mata kuliah yang diambil/dipilih secara bersamaan.

Dari hasil klasifikasi di atas, diperoleh jumlah frekuensi set mata kuliah, di mana jumlah tersebut harus memenuhi ketentuan phi $(\Sigma \geq \phi$ atau $\Sigma \geq 3)$. Hasil nya dapat dilihat pada tabel frekuensi itemset $\mathrm{F}=2$ berikut ini. 
Tabel 5 Tabel Frekuensi Itemset $\mathrm{F}=2$

\begin{tabular}{|r|r|r|}
\hline \multicolumn{2}{|r|}{ Item set } & $\mathbf{2}$ \\
\hline B & F & 4 \\
\hline B & G & 2 \\
\hline B & H & 4 \\
\hline B & I & 0 \\
\hline B & J & 0 \\
\hline B & K & 5 \\
\hline F & G & 7 \\
\hline F & H & 11 \\
\hline F & I & 1 \\
\hline F & J & 4 \\
\hline F & K & 4 \\
\hline G & H & 8 \\
\hline G & I & 1 \\
\hline G & J & 2 \\
\hline G & K & 2 \\
\hline H & I & 0 \\
\hline H & J & 2 \\
\hline H & K & 4 \\
\hline I & J & 2 \\
\hline I & K & 0 \\
\hline J & K & 0 \\
\hline
\end{tabular}

Dari tabel di atas didapati himpunan yang terbentuk adalah sebagai berikut:

$$
\mathrm{F}_{2}=\{(\mathrm{B}, \mathrm{F}),(\mathrm{B}, \mathrm{H}),(\mathrm{B}, \mathrm{K}),(\mathrm{F}, \mathrm{G}),(\mathrm{F}, \mathrm{H}),(\mathrm{F}, \mathrm{J}),(\mathrm{F}, \mathrm{K}),(\mathrm{G}, \mathrm{H}),(\mathrm{H}, \mathrm{K})\}
$$

Selanjutnya, kombinasi dari $F_{2}$, dapat digabungkan menjadi calon 3 item-set untuk $k=3$ (3 unsur), himpunan yang dapat terbentuk adalah: $\{(\mathrm{B}, \mathrm{F}, \mathrm{H}),(\mathrm{B}, \mathrm{H}, \mathrm{K}),(\mathrm{F}, \mathrm{G}, \mathrm{H}),(\mathrm{F}, \mathrm{J}, \mathrm{K}),(\mathrm{G}, \mathrm{H}, \mathrm{K})\}$

Selanjutnya kembali dilakukan penyusunan tabel untuk $\mathrm{k}=3$ tersebut dengan hasil berikut ini:

Tabel 6 Tabel frekuensi itemset $(\mathrm{F}=3)$

\begin{tabular}{|l|r|}
\hline Item set & $\mathbf{\Sigma}$ \\
\hline $\mathrm{B}, \mathrm{F}, \mathrm{H}$, & 3 \\
\hline $\mathrm{B}, \mathrm{H}, \mathrm{K}$ & 4 \\
\hline F, G,H & 5 \\
\hline F, J, K & 0 \\
\hline G, H, K & 1 \\
\hline
\end{tabular}

Dari tabel di atas didapati bahwa $\mathrm{F}_{3}=\{(\mathrm{B}, \mathrm{F}, \mathrm{H}),(\mathrm{B}, \mathrm{H}, \mathrm{K}),(\mathrm{F}, \mathrm{G}, \mathrm{H})\}$ memenuhi nilai ketentuan phi $(\Sigma$ $\geq \phi$ atau $\Sigma \geq 3$ ), oleh sebab itu kombinasi F3 dapat dilanjutkan dengan $k=4$. Himpunan yang terbentuk adalah: $\{(\mathrm{B}, \mathrm{F}, \mathrm{H}, \mathrm{K}),(\mathrm{F}, \mathrm{G}, \mathrm{H}, \mathrm{K})\}$. Hasil yang diperoleh adalah sebagai berikut: 
Prediksi Permintaan Mata Kuliah pada Semester Padat Dengan Menggunakan Teknik Association Rule Dengan Algoritma Apriori pada Fakultas Teknologi Informasi Universitas Advent Indonesia

Tabel 7 Tabel frekuensi itemset $\mathrm{F}=4$

\begin{tabular}{|l|l|}
\hline Item set & $\mathbf{\Sigma}$ \\
\hline $\mathrm{B}, \mathrm{F}, \mathrm{H}, \mathrm{K}$ & 3 \\
\hline $\mathrm{F}, \mathrm{G}, \mathrm{H}, \mathrm{K}$ & 0 \\
\hline
\end{tabular}

Dari hasil tersebut diperoleh hanya satu itemset yang memenuhi ketentuan phi $(\Sigma \geq \phi$ atau $\Sigma \geq 3)$, oleh sebab itu disimpulkan, untuk k=5 dan seterusnya tidak dapat dilanjutkan.

5. Aturan (Rule) yang digunakan

Rule yang digunakan adalah "if choose $x$ then choose $y$ ", di mana $x$ adalah antecedent (ss) dan $y$ adalah consequent (s). Berdasarkan rule tersebut, maka dibutuhkan 2 buah item dimana salah satunya sebagai antecedent dan sisanya sebagai consequent. Dari langkah di atas diperoleh 3 buah Fk, yaitu F2, F3 dan F4. F1 tidak disertakan karena hanya terdiri dari 1 unsur saja. Untuk antecedent boleh lebih dari 1 unsur, sedangkan untuk consequent terdiri dari 1 unsur.

Dari hasil tabel di atas, maka diperoleh 18 rule untuk $\mathrm{F}=2$, 9 rule untuk $\mathrm{F}=3$ dan 4 rule untuk $\mathrm{F}=4$. Selanjutnya dilakukan perhitungan support dan confidence dengan rumus:

$$
\begin{aligned}
\text { Support } & =\frac{\sum \text { item mata kuliah yang dipilih bersamaan }}{\sum \text { jumlah seluruh mahasiswa }} \times 100 \% \\
\text { Confidence } & =\frac{\sum \text { item mata kuliah yang dipilih bersamaan }}{\sum \text { jumlah mahasiswa pada bagian antecedent }} \times 100 \%
\end{aligned}
$$

Hasil perhitungan ditunjukkan pada tabel berikut ini:

Tabel 8 Tabel Kandidat Asosiasi Rule Untuk F=2

\begin{tabular}{|c|c|c|}
\hline $\begin{array}{c}\text { If antecedent then } \\
\text { Consequent }\end{array}$ & Support & Confidence \\
\hline If choose $B$ then choose $F$ & $(4 / 25) \times 100 \%=16 \%$ & $(4 / 5) \times 100 \%=80 \%$ \\
\hline If choose $F$ then choose $B$ & $(4 / 25) \times 100 \%=16 \%$ & $(4 / 15) \times 100 \%=27 \%$ \\
\hline If choose $B$ then choose $H$ & $(4 / 25) \times 100 \%=16 \%$ & $(4 / 5) \times 100 \%=80 \%$ \\
\hline If choose $H$ then choose $B$ & $(4 / 25) \times 100 \%=16 \%$ & $(4 / 16) \times 100 \%=25 \%$ \\
\hline If choose $B$ then choose $K$ & $(5 / 25) \times 100 \%=20 \%$ & $(5 / 5) \times 100 \%=100 \%$ \\
\hline If choose $K$ then choose $B$ & $(5 / 25) \times 100 \%=20 \%$ & $(5 / 6) \times 100 \%=83 \%$ \\
\hline If choose $F$ then choose $G$ & $(7 / 25) \times 100 \%=28 \%$ & $(7 / 15) \times 100 \%=47 \%$ \\
\hline If choose $G$ then choose $F$ & $(7 / 25) \times 100 \%=28 \%$ & $(7 / 12) \times 100 \%=58 \%$ \\
\hline If choose $F$ then choose $H$ & $(11 / 25) \times 100 \%=44 \%$ & $(11 / 15) \times 100 \%=73 \%$ \\
\hline If choose $H$ then choose $F$ & $(11 / 25) \times 100 \%=44 \%$ & $(11 / 16) \times 100 \%=69 \%$ \\
\hline If choose $F$ then choose $J$ & $(4 / 25) \times 100 \%=16 \%$ & $(4 / 15) \times 100 \%=27 \%$ \\
\hline If choose $J$ then choose $F$ & $(4 / 25) \times 100 \%=16 \%$ & $(4 / 5) \times 100 \%=80 \%$ \\
\hline If choose $F$ then choose $K$ & $(4 / 25) \times 100 \%=16 \%$ & $(4 / 15) \times 100 \%=27 \%$ \\
\hline If choose $K$ then choose $F$ & $(4 / 25) \times 100 \%=16 \%$ & $(4 / 6) \times 100 \%=67 \%$ \\
\hline If choose $G$ then choose $H$ & $(8 / 25) \times 100 \%=32 \%$ & $(8 / 12) \times 100 \%=67 \%$ \\
\hline
\end{tabular}


Jurnal TeIKa, Volume 9, Nomor 1, April 2019

\begin{tabular}{|l|l|l|}
\hline If choose $H$ then choose $G$ & $(8 / 25) \times 100 \%=32 \%$ & $(8 / 16) \times 100 \%=50 \%$ \\
\hline If choose $H$ then choose $K$ & $(4 / 25) \times 100 \%=16 \%$ & $(4 / 16) \times 100 \%=25 \%$ \\
\hline If choose $K$ then choose $H$ & $(4 / 25) \times 100 \%=16 \%$ & $(4 / 6) \times 100 \%=67 \%$ \\
\hline
\end{tabular}

Tabel 9 Tabel Kandidat Asosiasi Rule Untuk F=3

\begin{tabular}{|l|l|c|}
\hline $\begin{array}{l}\text { If antecedent then } \\
\text { Consequent }\end{array}$ & $\begin{array}{l}\text { Support } \\
\text { Confidence }\end{array}$ \\
\hline If choose $B$ and $F$ then choose $H$ & $(3 / 25) \times 100 \%=\quad 12 \%$ & $(3 / 5) \times 100 \%=60 \%$ \\
\hline If choose $B$ and $H$ then choose $F$ & $(3 / 25) \times 100 \%=\quad 12 \%$ & $(3 / 5) \times 100 \%=60 \%$ \\
\hline If choose $F$ and $H$ then choose $B$ & $(3 / 25) \times 100 \%=\quad 12 \%$ & $(3 / 15) \times 100 \%=20 \%$ \\
\hline If choose $B$ and $H$ then choose $K$ & $(4 / 25) \times 100 \%=\quad 16 \%$ & $(4 / 5) \times 100 \%=80 \%$ \\
\hline If choose $B$ and $K$ then choose $H$ & $(4 / 25) \times 100 \%=\quad 16 \%$ & $(4 / 5) \times 100 \%=80 \%$ \\
\hline If choose $H$ and $K$ then choose $B$ & $(4 / 25) \times 100 \%=\quad 16 \%$ & $(4 / 16) \times 100 \%=25 \%$ \\
\hline If choose $F$ and $G$ then choose $H$ & $(5 / 25) \times 100 \%=\quad 20 \%$ & $(5 / 15) \times 100 \%=33 \%$ \\
\hline If choose $F$ and $H$ then choose $G$ & $(5 / 25) \times 100 \%=\quad 20 \%$ & $(5 / 15) \times 100 \%=33 \%$ \\
\hline If choose $G$ and $H$ then choose $F$ & $(5 / 25) \times 100 \%=\quad 20 \%$ & $(5 / 12) \times 100 \%=42 \%$ \\
\hline
\end{tabular}

Tabel 10 Tabel Kandidat Asosiasi Rule Untuk F=4

\begin{tabular}{|l|l|l|}
\hline $\begin{array}{l}\text { If antecedent then } \\
\text { Consequent }\end{array}$ & Support & Confidence \\
\hline If choose $B, F$, and $H$ then choose $K$ & $(3 / 25) \times 100 \%=12 \%$ & $(3 / 5) \times 100 \%=60 \%$ \\
\hline If choose $B, H$, and $K$ then choose $F$ & $(3 / 25) \times 100 \%=12 \%$ & $(3 / 5) \times 100 \%=60 \%$ \\
\hline If choose $B, F$, and $K$ then choose $H$ & $(3 / 25) \times 100 \%=12 \%$ & $(3 / 5) \times 100 \%=60 \%$ \\
\hline If choose $F, H$ and $K$ then choose $B$ & $(3 / 25) \times 100 \%=12 \%$ & $(3 / 15) \times 100 \%=20 \%$ \\
\hline
\end{tabular}

Setelah diperoleh nilai support dan confidence untuk masing-masing kandidat, dilakukan perkalian antara support dan confidence untuk rules dengan nilai $\geq 80 \%$. Hasil perhitungan ditunjukkan pada tabel dibawah ini.

Tabel 11 Tabel Asosiasi Final (Supportx Confidence)

\begin{tabular}{|c|c|c|c|c|c|}
\hline $\begin{array}{l}\text { If antecedent then } \\
\text { Consequent }\end{array}$ & Support & & Confidence & & $\begin{array}{l}\text { Final Ass. } \\
\text { support } \quad X \\
\text { Conf }\end{array}$ \\
\hline If choose $B$ then choose $F$ & $(4 / 25) \times 100 \%=$ & $16 \%$ & $(4 / 5) \times 100 \%=$ & $80 \%$ & $13 \%$ \\
\hline If choose $B$ then choose $\mathrm{H}$ & $(4 / 25) \times 100 \%=$ & $16 \%$ & $(4 / 5) \times 100 \%=$ & $80 \%$ & $13 \%$ \\
\hline If choose $B$ then choose $K$ & $(5 / 25) \times 100 \%=$ & $20 \%$ & $(5 / 5) \times 100 \%=$ & $100 \%$ & $20 \%$ \\
\hline If choose $K$ then choose $B$ & $(5 / 25) \times 100 \%=$ & $20 \%$ & $(5 / 6) \times 100 \%=$ & $83 \%$ & $17 \%$ \\
\hline If choose J then choose $F$ & $(4 / 25) \times 100 \%=$ & $16 \%$ & $(4 / 5) \times 100 \%=$ & $80 \%$ & $13 \%$ \\
\hline If choose $B$ and $H$ then choose $K$ & $(4 / 25) \times 100 \%=$ & $16 \%$ & $(4 / 5) \times 100 \%=$ & $80 \%$ & $13 \%$ \\
\hline If choose $B$ and $K$ then choose $H$ & $(4 / 25) \times 100 \%=$ & $16 \%$ & $(4 / 5) \times 100 \%=$ & $80 \%$ & $13 \%$ \\
\hline
\end{tabular}

Dari Tabel 11 diketahui rule dengan nilai asosiasi final tertinggi ada pada itemset $\mathrm{F}=2$ yaitu If choose $B$ then choose $K$. 
Prediksi Permintaan Mata Kuliah pada Semester Padat Dengan Menggunakan Teknik Association Rule Dengan Algoritma Apriori pada Fakultas Teknologi Informasi Universitas Advent Indonesia

\section{KESIMPULAN}

Berdasarkan hasil analisa dan perhitungan di atas, maka rules yang dihasilkan adalah sebagai berikut:

1. "If choose $B$ then choose $F$ ". Jika mahasiswa memilih mata kuliah B (Algoritma), maka ia juga akan memilih mata kuliah $\mathrm{F}$ (Teknologi Baru) dengan nilai support $16 \%$ dan confidence $80 \%$.

2. "If choose $B$ then choose $H$ ". Jika mahasiswa memilih mata kuliah $B$ (Algoritma), maka ia juga akan memilih mata kuliah $\mathrm{H}$ (Jaringan Komputer) dengan nilai support $16 \%$ dan confidence $80 \%$.

3. "If choose $B$ then choose $K$ ". Jika mahasiswa memilih mata kuliah B (Algoritma), maka ia juga akan memilih mata kuliah K (Praktek Algoritma) dengan nilai support 20\% dan confidence $100 \%$.

4. "If choose $K$ then choose $B^{\prime}$. Jika mahasiswa memilih mata kuliah $\mathrm{K}$ (Praktek Algoritma), maka ia juga akan memilih mata kuliah B ( Algoritma) dengan nilai support $20 \%$ dan confidence $83 \%$.

5. "If choose $J$ then choose $F$ ". Jika mahasiswa memilih mata kuliah J (Aljabar Linear), maka ia juga akan memilih mata kuliah $\mathrm{F}$ (Teknologi Baru) dengan nilai support $16 \%$ dan confidence $80 \%$.

6. "If choose $B$, and $H$ then choose $K$ ". Jika mahasiswa memilih mata kuliah $\mathrm{B}$ (Algoritma) dan $\mathrm{H}$ (Jaringan Komputer), maka ia juga akan memilih mata kuliah K( Praktek Algoritma) dengan nilai support $16 \%$ dan confidence $80 \%$.

7. "If choose $B$, and $K$ then choose $H$ '. Jika mahasiswa memilih mata kuliah $\mathrm{B}$ (Algoritma) dan $\mathrm{K}$ (Praktek Algoritma), maka ia juga akan memilih mata kuliah $\mathrm{H}$ (Jaringan Komputer) dengan nilai support $16 \%$ dan confidence $80 \%$.

Rule dengan nilai asosiasi final tertinggi ada pada rule "If choose $B$ then choose $K$ ", yaitu: Jika mahasiswa memilih mata kuliah B (Algoritma), maka ia juga akan memilih mata kuliah K (Praktek Algoritma) dengan nilai support $20 \%$ dan confidence $100 \%$.

\section{Referensi}

[1] J. Han, M. Kamber and J. Pei, Data Mining Concept and Techniques 3rd edition, Waltham, MA: Morgan Kaufmann, 2012.

[2] M. Kaur and S. Kang, "Market Basket Analysis: Identify the changing trends of market data using association rule mining," Elsevier (Procedia Computer Science 85 ( 2016 ) 78 - 85) , pp. 78-85, 2016.

[3] Widodo, "Prediksi Mata Kuliah Pilihan dengan Aturan Asosiasi," e-Indonesia Initiative 2008 (eII2008), Jakarta, 2008.

[4] Erwin, "Analisis Market Basket Dengan Algoritma Apriori dan FP-Growth," JURNAL GENERIC, pp. 26-30, 2009.

[5] M. A. Syaifullah, "IMPLEMENTASI DATA MINING ALGORITMA APRIORI PADA SISTEM PENJUALAN," Yogyakarta, 2010.

[6] A. Raorane, R. Kulkarni and B. Jitkar, "Association Rule - Extracting Knowledge Using Market Basket Analysis," Research Journal of Recent Sciences Vol. 1(2), 19-27, Feb. (2012), pp. 19-27, 2012.

[7] V. S. Kumar, R. Renganathan, C. VijayaBanu and I. Ramya, "Consumer Buying Pattern Analysis using Apriori Association Rule," International Journal of Pure and Applied Mathematics Volume 119 No. 72018 , , pp. 2341-2349, 2018.

[8] G. Suchacka and G. Chodak, "Using association rules to assess purchase probability in online stores," Inf Syst E-Bus Manage, SPRINGER, vol. 15, pp. 751-780, 2017. 